\section{秋田駒ヶ岳の植被構造土}

$$
\text { 井上克弘・冨岡成悦・千葉斐子・吉田 稔 }
$$

秋田駒ヶ岳火山群男女岳 (標高 $1,637 \mathrm{~m}$ ) 火口底に扝 いて植被構造土を観察した（写真 1 )。火口底は標高 $1,615 \mathrm{~m}$, 直径約 $80 \mathrm{~m}$ の浅い皿状凹地をなし，融雪時 一時的に湛水する（5 月中旬で水深約 $30 \mathrm{~cm}, 6$ 月上旬 干上がる)。火口は僅かな高さの違いが植生に反映し, 次の 3 区に分けられる。

A. 八イマッ域：火口内周縁斜面では八イマッ，八 クサンシャクナゲ，ミネヤナギ等の嫌雪的な矮小灌木 類が優占。植被構造土は存在しない。

B. チングルマ域：融雪時, 水面よりやや上方にあ るが, 比較的湿潤であり, 好雪的なチングルマが優占。 直径 30 200 cm の凍結はけ $F^{(1)}$ が各所に発達。凍結は げは底の平らな凹地で，深さ約 $5 \mathrm{~cm}$ の潘洫直な周 壁で限られている。凍結はげ部分は風蝕を受け，その 表面には直径 1 $5 \mathrm{~cm}$ の火山碩が散在する。

C. シロバナトウウチソウ,ミヤマノガリヤス,スギゴ ケ域：融雪時に湛水する楕円形（径 $16 \times 24 \mathrm{~m}$ ) をなす 部分で約 100 個の凍結坊主 ${ }^{(1)}$ が発達。凍結坊主の形態 : 直径 $40 \sim 130 \mathrm{~cm}$, 高さ $10 \sim 65 \mathrm{~cm}$ の半球形。中心部 で規模が大きく,数個の凍結坊主が重なりあっている。 $B \rightarrow C$ 移行部には小規模な凍結坊主の形成が進行中。 植生: 融雪時水面上にある凍結坊主部分はシロバナト ウウチソウ，ミヤマノガリヤス等適潤性植物が優占で
あるが，水面下にある溝部分は砂磁地もしくはスギゴ ケが優占。

A， B，Cはいずれも土壌は同質で細粒質の秋田駒ヶ 岳 $\mathrm{b}$ 統 $(\mathrm{Ak}-\mathrm{b})$ 降下火山灰 $(2,770 \pm 260$ yr. B.P. $)$ か ら成る ${ }^{(2)}$ 。

男女岳山頂部は冬季西〜北西の卓越風をま之もに受 けるため積雪が少なく，乙かも火口底部分は土壌水分 が多く，八イマッの侵入から免れている。また，岩手 山測候形 (標高約 $1,771 \mathrm{~m}$ ), 藤七温泉 (標高 $1,440 \mathrm{~m}$ )

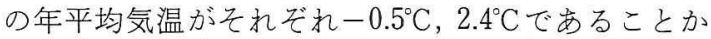
ら, 秋田駒ヶ岳山頂付近の年平均気温は $1^{\circ} \mathrm{C}$ 前後之推 定される。したがって, 秋田駒ケ岳の植被構造土は融 凍・攪拌による不等凍上の結果形成された現成の周水 河地形と考光られる。

な执，秋田駒ケ岳アミダ池西側湿原拉よび岩手山大 地獄火口内の御苗代湖南側湿原にも同様の植被構造土 が観察された。また，男女岳南麓斜面には階段土が形 成されている。

最後にこの調查を実施するにあたり，便宜を計って 頂いた生保内営林署の関係者に感謝する。

\section{文 献}

井上克弘 (1978)：秋田駒ヶ岳火山噴出物の ${ }^{14} \mathrm{C}$ 年代, 地球科学 $32 \quad 221 \sim 223$

小疇 尚 (1965)：大雪火山群の構造土, 地理学評論 $38 \quad 179 \sim 199$

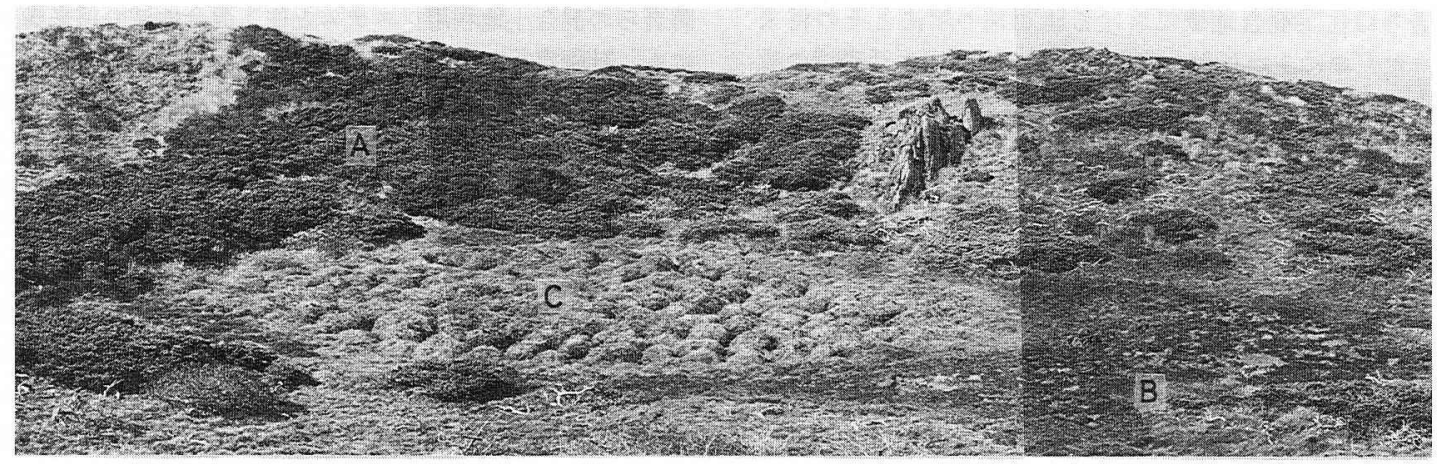

写真 1. 秋田駒ヶ岳火山群男女岳火口底における被植構造土

A. ハイマッ域，B． チングルマ域（凍結はげ)，C. シロバナトウウチソウ，ミヤマノ ガリヤス，スギゴケ域（凍結坊主）

\title{
Frost Hummocks and Frost Scars Found on MT. Akita-Komagatake
}

\section{Katsuhiro Inoue, Seietsu TomiokA, Ayako CHIBA and Minoru YoshidA}

The frost hummocks and the frost scars, which are active periglacial landforms, develop on the crater bottom of Mt. Onamedake $(1,637 \mathrm{~m})$ in Akita-Komagatake volcanic groups. The vegetation in the crater is divided into three groups, Pinus pumila (A), Sieversia pentapetala (B), and Sanguisorba albiflora and Calamagrostis purpurascens (C). Well-developed frost hum- mocks entirely covered with dense vegetation are observed on the (C) group. The diameter and the height of frost hummocks, respectively, are 40 to $130 \mathrm{~cm}$ and 10 to $65 \mathrm{~cm}$. The frost scars develop on the (B) group. The soil at the crater bottom is composed of the AK-b tephra (radiocarbon dated at 2,770 \pm 260 yr.B,P.)erupted from Akita-Komagatake Volcano. 